\title{
Improvement of Educational Quality: Bridging The Total Quality Management to Map Students' Life Skills at Polytechnic of Health-Ministry
}

\author{
Aan Komariah ${ }^{1}$, Nia Daniati ${ }^{2}$, Dedy Achmad Kurniady ${ }^{3}$, Aceng Muhtaram Mirfani ${ }^{4}$, Yayah \\ Rahyasih $^{5}$ \\ 1,2,3,4,5 Universitas Pendidikan Indonesia, Indonesia
}

\begin{abstract}
This research was conducted to obtain a description that the Life Skill-Based Academic Service which is formulated based on the results of the evaluation can improve students' life skills of Higher Education Department of Dental Nursing Polytechnic of healthministry, Ministry of Health, Tasikmalaya and Bandung. The profile of academic service quality for Dental Nursing at Polytechnic of health-ministry, Ministry of Health, Tasikmalaya and Bandung, has not fully focused on improving life skills more thoroughly including life skills for the business world. Improvement and development of life skills through a number of learning activities, work practices and graduates who are ready to compete in the world of work. Leadership policy in implementing life skill-based academic service quality, oriented to the world of work. The formulation of policies for quality assurance is an elaboration of the vision and mission in order to produce graduates who are competent in the world of work. There is no policy evaluation specifically related to life skills. Evaluation is carried out on the output in the form of graduate and student user satisfaction with the service system. The Total Quality Management (TQM) system for service quality / academic life skill-based management has not been fully supported by the 10 main elements of TQM, especially the scientific approach. Planning focuses on main customers with internal customer support. Quality improvement is carried out by involving quality assurance units, structural and staff as team work. The improvement of the TQM system focuses on providing educational services oriented to the world of work.
\end{abstract}

Keywords:

Total Quality Management, Students' Life Skills, Educational Quality.

Article Received: 18 October 2020, Revised: 3 November 2020, Accepted: 24 December 2020

\section{INTRODUCTION}

The increasing need of society for graduates of dental nursing higher education encourages changes in the concept of graduate quality (Hood, 2009). Harper highlighted the skills problems of the dental nursing workforce (Harper et al., 2019). Changes in the volume and type of dental care required demand the creation of new roles in the dental profession. This condition demands adequate planning of the dental workforce. Previous research emphasize interprofessional education (IPE) to improve practical skills in nursing and dental health (Abernethy et al., 2009; Borders et al., 2015; Dawson et al., 2015; de Oliveira et al., 2018; Rose et al., 2015). Donovan focuses on teaching staff issues related to the quality of education services (H. S. Donovan \& Ward, 2001). It was explained that there is a high need for competence for dental health educators, formal professional development, collaboration among colleagues to improve consistency, communication, inclusion and calibration; included in the teaching methodology. Deeper study shows the importance of quality dental practice that is supported by knowledge of anatomy for higher education (Gazi, 2019; Obicci, 2019; Sampson, Udoh, Sampson, \& Abraham, 2019). Borders et al., (2015) and Hamil (2017) emphasized the need to adapt the dental education system to the needs of society and promote the quality of education. Sabalic \& Schoener (2017) confirms the relationship between knowledge and practice for dental nursing school graduates. Some experts have indicated that dental nursing school graduates experience shock (Azevedo et al., 2010; Borders et al., 2015; de Oliveira et al., 2018; P. Donovan, 1998; Fernandes Azevedo et al., 2018; Hamil, 2017; Hashemian et al., 2019). Dental health education graduates are required to have the knowledge and skills needed to appear as health professionals and have the ability to take advantage 
of critical thinking (Nadeem et al., 2020; Ahmad \& Ahmad, 2019).

Based on the concepts put forward about the input, process and output of dental nursing colleges, it can be concluded that there is a demand for the quality of graduates in accordance with the needs of the growing and increasing world of work (Price, 2019; Ahmad \& Ahmad, 2018). Improvements in every aspect of higher education are oriented towards the availability of dental nursing graduates with professional skills (Elhadd et al., 2007; Pee et al., 2002; Ahmad \& Sahar, 2019). This emphasizes the importance of providing students with skills related to the world of work. Skills in accordance with the needs of society and the ability to think critically as a professional in dental nursing as a proposition that is the basis for the development of a dental nursing school. This means that graduates have professional abilities and are ready to work. Life skills are needed by students. WHO emphasizes the importance of life skills in education (Organization, 2001). Some experts explain that generic skills and other competencies in work life are considered critical (Elhadd et al., 2007; Feather \& Fry, 2009; Fried et al., 2004; Gordon et al., 2009; Pee et al., 2002; Tucker, 2018).

Life skill as a dynamic ability to adapt and behave positively to manage effectively with the demands and challenges of life. Findings in previous research related stated that the challenge in dental health education is the competency qualification of the dental hygiene program which is in line with the Commission on Dental Accreditation (CODA) (Boykin et al., 2005; Camp \& Walters, 2016; Dang et al., 2017; Jääskelä et al., 2018; Perry et al., 2008; Wood et al., 2015). One of researcher describes the existence of a "mismatch" between education and the skills required in higher education (Martin et al., 2018). The context of risk and uncertainty for the journey of life as a basis for choosing a college is very important (Camp \& Walters, 2016). Manogue et al. (2011) focuses on curriculum development. Bennet et al., (2006) explain how to see the challenges and trends, as well as the need for changes to the climate of
Higher Education (HE) to teach diverse career skills, knowledge and creativity that are valued for entering sustainable careers. Camp \& Walters (2016) developed a program to facilitate the gap between existing skills and existing needs and challenges.

Manogue et al. (2011) emphasized the curriculum structure, content, learning and assessment of dental education. Fallows \& Steven (2000) explain how curriculum development is to provide life skills so that graduates are ready to work. Bennet et al., (2006) emphasize the need for the acquisition and development of core and generic skills in higher education and employment. Kurtdede-Fidan \& Aydogdu (2018) stated regarding the role of teachers in the acquisition of life skills in university students. Sopka et al. (2012) suggested practice as an activity to prepare skills. Bazana et al. (2018) suggests the importance of institutional culture and the implementation of labor laws by universities for skills transferability. Ali et al. (2017) demonstrates curriculum design and implementation in dental health schools and proposes core skills needed at graduation and in the future. The importance of developing life skills in dental nursing education is stated by Girdler \& Smith (1999), soft skills \& hard skills according to Gonzales et al. (2012), and according to the needs of the workforce (Peterson, 2019). Duckworth et al., (2007) describes faculty support, development, and lifelong learning that is more efficient and effective in improving the skills of dental nursing students. Improving the health and well-being of students through the development of life skills is very important given that universities are often the first time young people take responsibility for their own health and well-being (Ridner, 2004).

The results of this study are expected to provide input in the form of a contribution to the concept of dental nursing education in preparing graduates with quality and high selling value in the local, regional, national and even international world. This is especially important in order to meet the demands of reform and enter the era of globalization, as an era of quality competition which is full of various challenges. 


\section{RESEARCH METHODOLOGY}

\section{Research Approach}

Researchers used a qualitative approach. The research was designed to gain an understanding of the meaning behind the actions of the Health Polytechnic of the Ministry of Health, Department of Dental Nursing (JKG), West Java in providing life skill-based academic services in improving the quality entrepreneurial orientation of higher education graduates from the Department of Dental Nursing, Polytechnic of health-ministry of the Ministry of Health, West Java. This descriptiveanalytic study will focus on case studies of evaluating the quality of life-skill-based academic services in improving the quality of graduate entrepreneurship orientation in the JKG Polytechnic of health-ministry of the Ministry of Health, West Java .

\section{Research Location and Participants}

Participants in this study consisted of several data sources according to their position and role, the subject or informant was used as a source of data and information for this research, as follows:

1) Head of the Department, 2) Secretary of the Department, 3) Head of Study Program, 4) Lecturer, 5) Staff Education, 6) Students, 7) Alumni, and 8) Users. The technique of collecting data sources is using purposive technique. Another technique used to source data through interviews is the snowball sampling technique as needed. Snowball sampling technique is used to enrich information in interviews, observations and studies of written data as a basis for deepening understanding according to research objectives.

\section{Data Collecting Technique}

Data collection methods in this study were carried out according to Creswell \& Garrett (2008), namely: 1) Observation method: this method was carried out using instruments, in the form of observation sheets and questionnaires in the implementation of life skill-based quality management evaluation using the CIPP model evaluation method; 2) Interview method: prior to conducting interviews with research subjects, the researcher prepares a question frame in the implementation of life skill-based quality management evaluation using the CIPP model evaluation method. This method is used to clarify the results of observations so that problems can be seen in depth and detail; 3) The FGD discussion method functions as data collection and data analysis, especially in model development; and 4) Documentation is used to find data about things or variables in the form of notes, books, newspapers, magazines, agendas, etc.

\section{Data Analysis Technique}

The steps of the analysis as follows: 1) Processing and preparing the data for analysis, 2) Read the entire data, 3) Analyze more data by coding the data, 4) Apply a coding process to describe the settings, people, categories and themes to be analyzed, 5) Show how these descriptions and themes will be restated in a qualitative narrative/report., and 6) The final step in data analysis is to interpret or interpret the data. Asking questions will help researchers reveal the essence of an idea (Lincoln \& Guba, 1985).

\section{RESULTS AND DISCUSSION}

\section{Life skill-based academic/service quality management TQM system}

The suitability between the quality produced and the quality expected by customers is the main indicator of the success of implementing qualitybased education in a sustainable manner. School quality service system planning sets targets based on the Vision and Mission. The formulation becomes the domain of the leadership policy makers along with other members of the organization. The formulation of the vision and mission is only from the institution. The formulation of the vision and mission involves members of the organization. Vision and Mission become the foundation of values for every activity of the organization. According to DS, the formulation of the vision and mission is based on the values of education and the role and function of higher education (MP. Plan. 1. PVM. Lecturer. DS. Tsk).

The vision of the institution is based on the functions and roles of higher education institutions for the community. The output of the institution is 
graduates who have professionalism in the health sector. The same thing was stated by Fn that the values that became the reference for designing the vision were the goals of national education. The function and role of the institution is clearly stated in this vision (MP. Plan. 1. PVM. Lecturer. Fn. Tsk). The formulation of the Vision and Mission describes a reflection on the higher education paradigm in order to produce new thoughts and concepts about higher education development that can be used as a basis for thinking and how to act correctly. The vision and mission describes the paradigm and articulation of the roles and functions of tertiary institutions majoring in dental nursing.

The paradigm is expressed in the form of a system that functions to improve quality, productivity, relevance and expand opportunities for community members to obtain quality dental nursing education. The points about the vision and mission are put forward by the Head of Study Program (MP. Plan. 1. PVM. Kaprd. Tsk). The vision and mission design is a form of reflective awareness of the existence of higher education institutions in the era of globalization and industrial revolution 4.0. Being a leading health higher education institution in quality is understood as an effort to provide the best for the nation. It was stated by Ak that there was a paradigm shift in higher education governance that was more focused on students. The focus on professionalism for graduates is an important aspect that must be fulfilled, moral and intellectual issues are issues of concern for high-quality institutions in realizing society in the global era (MP. Plan. 1. PVM. Lecturer. Ak. Tsk).

The vision and mission of a health higher education institution is understood as a constructive institution that aims to prepare professional human resources with adequate soft skills through a number of systematic and planned learning and educational processes. This is as conveyed by one of the senior lecturers that "the formulation of the vision and mission is based on an ethical reflective understanding of the external environmental conditions in which the school is located". Vision does not only contain positive meanings. Vision and Mission are the result of ethical reflection on the function of the institution, the results of the identification of problems in higher education and changes in an increasingly competitive environment. Vision and Mission determine each of the design goals and the expected final form of the organization. Vision and mission have ethical meaning. Vision and mission contain normative and positive aspects. The identification of each quality process using TQM tools is still rarely used. Limited resources, such as human resources and budget, mean that the identification process is only carried out based on several observations and student achievements, both from graduation and at the time of completion of study. The identification process is hampered by the availability of personnel who have special duties and responsibilities in quality assurance by using the TQM measurement tool both qualitatively / quantitatively on an ongoing basis.

Basically, process identification illustrates that the effort to achieve quality is a process. Sequential integration of human resources, materials, methods, machines and equipment that support the system to achieve quality in higher education services in the Department of Dental Nursing at polytechnic of health-ministry under the Ministry of Health, Tasikmalaya in order to improve life skills incorporated in the overall quality system of the institution Process identification using TQM tools such as FGD (Focus Group Discussion) or Brainstorming has been carried out. Quality management planning in general related to polytechnic of health-ministry services involving internal quality assurance unit staff and with related parties has been carried out both formally in the activities of related ministry agencies and from joint activities initiated in FGD or Brainstorming.

Specifically, the use of TQM tools can help identify each planning stage in the education delivery process, but in general the process itself is rarely done. It is recognized that the evaluation for the preparation of quality planning is mostly done at the end of the year or semester or before accreditation. (MP. Plan. 4. Iden. Pro. AAn. Tsk). 
The same thing was stated by Tr that observation, achievement of graduates according to targets, student acceptance in the world of work, and the number of graduates each year are observed and analyzed data for quality planning in the following year (MP. Plan. 4. Iden. Pro. Tr. Tsk), while observations during the process were not carried out. Institutions have difficulty identifying the quality improvement process using the TQM measurement tool both qualitative / quantitative on an ongoing basis except for the final result.

\section{Student profiles of life skill-based learning models in the Dental Nursing Department}

In general, lecturers understand life skills as general skills needed by students to compete in this global era. One of the lecturers said that life skills are defined as a number of general skills that should be possessed by graduates in order to compete in the global era either to create jobs or work in related institutions. The results of interviews and observations of students in the learning process and daily social interactions indicate that communication skills and interpersonal skills are indicated by the ability to communicate both verbally and non-verbally, such as: 1) active listening, 2) expressing feelings; give feedback (without blaming) and accept feedback. The students' communication skills are quite good, especially since it is emphasized in the dental nursing profession. Students are required to produce qualified and globally competitive Dental Nursing Associate graduates, producing competent graduates with skilled excellence in the field of dental nursing (LS. KKI. Interpersol. Lecturer. An. Tsk). Students as prospective dental nurses are required to have good communication skills, we strive so that the learning process can lead to the formation of good communication skills between patients and nurses, in accordance with the perspective of dental health care that is centered on interpersonal relationships in its services (LS. KKI. Interpersol. Cur. An. Tsk).

The demands for communication skills are very high. Students learn to listen to patient complaints, as well as listen to or process suggestions from others as a basis that leads to professional responsibility. By listening to information from patients in order to find out the problems faced by these patients. In addition to listening, dental nurses can explore other relevant information to support the implementation of care services later (WLS. KKI. Interpersol. Lecturer. CR. Tsk). Students learn to build empathy (the ability to listen, understand the needs and circumstances of others and express understanding through promotive activities of dental nursing services in primary schools or in the community through collaborative mechanisms. Lecturers and student groups in simple promotional, preventive and curative activities) teamwork that expresses respect for others' contributions and different styles, assesses one's own abilities and contributes to the group Business activities initiated by entrepreneurship lecturers with study programs according to students affect skills and persuasion, networking skills and motivation. moral responsibility includes caring for clients, empathy and with feelings of compassion. As dental nurses, consider patients as recipients of quality services based on standards of behavior and professional ethics (W. LS. KKI. Empati. Dosen. CR. Tsk). They learn to provide care services with an ethicalbased approach where dental nurses value patients, are willing to generously provide something useful, act fairly by explaining and providing information about the benefits and risks faced, and supporting the patient's right to make decisions (W. LS. KKI. Empati. Lecturer. An. Tsk).

Students are required to be able to work together and teamwork to express respect for patients and society and to be able to assess their ability to provide dental nursing services in order to grow awareness of efforts to improve skills. An added that work as a nurse is not only done alone, nurses learn to work together with fellow nurses or with the community to encourage healthy living behaviors, for example to promote dental nursing, they must have the ability to work together and teamwork. The team expresses respect for people. Others' contributions and different styles, assessing their own abilities and contributing to the group (W. LS. KKI. Koperasi. Lecturer. An. Tsk). 
Based on the analyzed findings, there are several research implications that can be examined more deeply in future research. The quality of academic services for Dental Nursing at polytechnic of health-ministry under the Ministry of Health, Tasikmalaya and Bandung, has not fully focused on increasing life skills more thoroughly including life skills for the business world so that Dental Nursing graduates work more than the business world. The leadership policy has not focused on implementing the quality of life skill-based academic services which is oriented towards the business world. Policies have not been able to direct the academic service system that can guarantee graduates who are ready for the world of work and the world of business. The TQM structure based on life skills is still lacking. The main elements supporting the structure of TQM are more oriented towards the world of work than the world of business.

Improving the quality of life skill-based academic services in the learning process is constrained by the support of practicum facilities and the proportionality of the qualifications and educational backgrounds of lecturers. Recommendations are formulated based on: 1) Changes in the profile of the quality of academic services that are oriented towards producing graduates who are ready to become entrepreneurs with a number of knowledge, skills and character as entrepreneurs; 2) Policy at the study program level as an extension of the Polytechnic of healthministry policy to encourage the profile of academic services to produce for the world of work and the business world; 3) The need to implement an internal quality system design at the study program level to ensure the implementation of academic services that direct students to have adequate life skills not only to meet the needs of the world of work but the business world by optimizing the 10 main elements of TQM which focus on life skills for business; and 4) It is better if a life skillbased service quality assurance system is developed at the study program level such as SOP, documentation system, quality control system and improvements, especially facilities and infrastructure / facilities for entrepreneurship practicum labs and the proportionality of lecturers' qualifications so that training / workshops on life skills are needed.

\section{DISCUSSION}

TQM is not only a tool. TQM is a philosophy directing organizational way of thinking on the efforts to achieve the goals. TQM applied by educational institutional refers to a study by Koksal (2007) and Gaspersz (2005) stating that quality is all of thing having ability of meeting the need of customers. TQM aims to build customer satisfaction as a cycle system namely 1) Plan , 2) Do 3 ) check, 4) action as a function unity.

The academic service system is developed based on concept of Parasuraman et al (1990) in the form of SERVQUAl Model (service quality) which is built by comparison of two main factors namely customer perspective on perceived service that they accept and expected service. Service dimensions are: 1) Reliability : 2) Responsiveness : 3) assurance : 4) Empathy: 5) Tangible which are managed by the TQM system to provide satisfaction to main customers such as university students, institutional intern customers and tertiary customers such as government, use of dental nursery graduates and the community. Service dimensions are used as value attributes which are attached to each academic and non academic activities, access, dental nursery study program and reputation which are developed as the best provider of nursing education service.

In the effort of facilitating life-skill based academic service system development, practical evaluation theory refers to Tobins (2005), namely: 1) narrative summary about strength and weakness of instructors of school administrator 2) development testing: to test technical effectiveness 3) material revision in informative evaluation description; building feedback mechanism for the faculty to create changes based on the number of students, partners and administration evaluation. 4) feedback from students, evaluation of students on performance of instructors bringing significant weights in overall assessment. 5) level of 
utilization.

Entrepreneurship theory in the context of implementation of academic service is developed based on a paradigm stated by Schumpeters (1939) on creativity and innovation by a destructive way of value market. The destructive values by nursing education institution are values which do not direct academic service to the purpose to improve graduate entrepreneurship. Creativity and innovation, bravery for risk-taking, aggressive to challenge market needs of graduate use including student needs. Schumpeter (1939) described that entrepreneur function is not as a creator or inventor of new combinations (except for coincidence), but it is more as implementer of creative combination by destructing established to better order.

Values show entrepreneurship orientation such as autonomy, innovation, proactive, competitive aggressively and risk taking. The three dimensions, namely innovation, proactive and risk taking have been adopted more frequently in defining entrepreneurship orientation (Lumpkin \& Dess, 1996). Entrepreneurship orientation model focuses on development of innovation, proactive and risk-tasking entrepreneurship spirits. University students are encouraged to achieve, identity, create and launch new business chances and strategic update to give service of dental nursery in the community both promotive, preventive and curative with various non-work professions but as health entrepreneurs.

\section{CONCLUSIONS AND SUGGESTIONS}

\section{Conclusions}

Based on the results of the study, it was found that the Quality Mode 1 Life Skill-Based Academic Service which was formulated based on the results of the evaluation using the CIPP model can improve the entrepreneurial behavior of graduates of Higher Education Department of Dental Nursing at polytechnic of health-ministry under the Ministry of Health, Tasikmalaya and Bandung. The profile of the academic service quality for Dental Nursing at polytechnic of health-ministry of the Ministry of Health, Tasikmalaya and Bandung, has not fully focused on increasing life skills more thoroughly including life skills for the business world. Improvement and development of life skills through a number of learning activities, work practices and graduates who are ready to compete in the world of work.

Leadership policy in implementing life skillbased academic service quality, oriented to the world of work. The formulation of policies for quality assurance is an elaboration of the vision and mission in order to produce graduates who are competent in the world of work. There is no policy evaluation specifically related to life skills. Evaluation is carried out on the output in the form of graduate and student user satisfaction with the service system. The life skill-based academic / service quality management TQM system has not been fully supported by the 10 main elements of TQM, especially the scientific approach. Planning focuses on main customers with internal customer support, namely lecturers. Quality improvement is carried out by involving quality assurance units, structural and staff as team work. The improvement of the TQM system focuses on providing educational services oriented to the world of work so that the outcomes can preserve the qualities.

\section{REFERENCES}

[1] Abernethy, A. P., Herndon II, J. E., Wheeler, J. L., Day, J. M., Hood, L., Patwardhan, M., Shaw, H., \& Lyerly, H. K. (2009). Feasibility and acceptability to patients of a longitudinal system for evaluating cancer-related symptoms and quality of life: pilot study of an e/Tablet data-collection system in academic oncology. Journal of Pain and Symptom Management, 37(6), 1027-1038.

[2] Ahmad I, Ahmad S. Multiple Skills and Medium Enterprises' Performance in Punjab Pakistan: A Pilot Study. Journal of Social Sciences Research. 2018; Special, (4):44-9.

[3] Ahmad I, Ahmad S. The Mediation Effect Of Strategic Planning On The Relationship Between Business Skills And Firm's Performance: Evidence From Medium 
Enterprises in Punjab, Pakistan. Opcion. 2019;35(24):746-78.

[4] Ahmad, I., Sahar. Waste Management Analysis From Economic Environment Sustainability Perspective. International Journal Of Scientific \& Technology Research. 2019; 8(12), 1540-1543.

[5] Ali, K., Zahra, D., Coelho, C., Jones, G., \& Tredwin, C. (2017). Academic performance of undergraduate dental students with learning disabilities. British Dental Journal, 222(3), 205-208.

[6] Azevedo, M. S., Vilas Boas, D., Demarco, F. F., \& Romano, A. R. (2010). Where and how are Brazilian dental students using Glass lonomer Cement? Brazilian Oral Research, 24(4), 482-487.

[7] Bazana, S., McLaren, L., \& Kabungaidze, T. (2018). Transforming while transferring: An exploratory study of how transferability of skills is key in the transformation of higher education. Transformation in Higher Education, 3(1), 1-14.

[8] Bennet, L., Roelfsema, V., Pathipati, P., Quaedackers, J. S., \& Gunn, A. J. (2006). Relationship between evolving epileptiform activity and delayed loss of mitochondrial activity after asphyxia measured by near-infrared spectroscopy in preterm fetal sheep. The Journal of Physiology, 572(1), 141-154.

[9] Borders, L. D., Brown, J. B., \& Purgason, L. L. (2015). Triadic supervision with practicum and internship counseling students: A peer supervision approach. The Clinical Supervisor, 34(2), 232-248.

[10] Boykin, A. W., Tyler, K. M., \& Miller, O. (2005). In search of cultural themes and their expressions in the dynamics of classroom life. Urban Education, 40(5), 521-549.

[11] Camp, H. C., \& Walters, G. E. (2016). A dual perspective on AP, dual enrollment, and honors.

[12] Creswell, J. W., \& Garrett, A. L. (2008). The "movement" of mixed methods research and the role of educators. South African Journal of Education, 28(3), 321333.

[13] Dang, S., Feng, S., Tien, J., Peters, C. J., Bulkley, D., Lolicato, M., Zhao, J., Zuberbühler, K., Ye, W., \& Qi, L. (2017). Cryo-EM structures of the TMEM16A calcium-activated chloride channel. Nature, 552(7685), 426-429.

[14] Dawson, K. S., Bryant, R. A., Harper, M., Tay, A. K., Rahman, A., Schafer, A., \& Van Ommeren, M. (2015). Problem Management Plus (PM+): a WHO transdiagnostic psychological intervention for common mental health problems. World Psychiatry, 14(3), 354.

[15] de Oliveira, V. F., Bittencourt, M. F., Pinto, I. F. N., Lucchetti, A. L. G., da Silva Ezequiel, O., \& Lucchetti, G. (2018). Comparison of the Readiness for Interprofessional Learning and the rate of contact among students from nine different healthcare courses. Nurse Education Today, 63, 64-68.

[16] Donovan, H. S., \& Ward, S. (2001). A representational approach to patient education. Journal of Nursing Scholarship, 33(3), 211-216.

[17] Donovan, P. (1998). School-based sexuality education: the issues and challenges. Family Planning Perspectives, 30(4), 188-193.

[18] Duckworth, A. L., Peterson, C., Matthews, M. D., \& Kelly, D. R. (2007). Grit: perseverance and passion for long-term goals. Journal of Personality and Social Psychology, 92(6), 1087.

[19] Elhadd, T. A., Al-Amoudi, A. A., \& Alzahrani, A. S. (2007). Epidemiology, clinical and complications profile of diabetes in Saudi Arabia: a review. Annals of Saudi Medicine, 27(4), 241-250.

[20] Fallows, S., \& Steven, C. (2000). Building employability skills into the higher education curriculum: a university-wide initiative. Education+ Training. 
[21] Feather, A., \& Fry, H. (2009). Key aspects of teaching and learning in medicine and dentistry. A Handbook for Teaching and Learning in Higher Education, 424.

[22] Fried, J. L., Reid, B. C., \& DeVore, L. E. (2004). A comparison of health professions student attitudes regarding tobacco curricula and interventionist roles. Journal of Dental Education, 68(3), 370-377.

[23] Gaspersz, Vincent. 2005. Total Quality Management. Jakarta: PT. Gramedia Pustaka Utama

[24] Gazi, A. K. (2019). People With Vulnerabilities To Cyclone In The Coastal Area Of Bangladesh: An Overview. International Journal of Social Sciences and Economic Review, 1(2), 80-91. doi:https://doi.org/10.36923/ijsser.v1i3.43

[25] Girdler, N. M., \& Smith, D. G. (1999). Prevalence of emergency events in British dental practice and emergency management skills of British dentists. Resuscitation, 41(2), 159-167.

[26] Gonzales, C. H., Leroy, G., \& De Leo, G. (2012). Augmentative and alternative communication technologies. In Computer engineering: Concepts, methodologies, tools and applications (pp. 1164-1180). IGI Global.

[27] Gordon, J. S., Albert, D. A., Crews, K. M., \& Fried, J. (2009). Tobacco education in dentistry and dental hygiene. Drug and Alcohol Review, 28(5), 517-532.

[28] Gupta, B., Nanda, A., Jain, V., \& Verma, M. (2017). Interprofessional education: A reform plan for collaborative. Contemporary Clinical Dentistry, 8(1), 3.

[29] Hamil, L. M. (2017). Looking back to move ahead: interprofessional education in dental education. Journal of Dental Education, 81(8), eS74-eS80.

[30] Harper, N. J., Mott, A. J., \& Obee, P. (2019). Client perspectives on wilderness therapy as a component of adolescent residential treatment for problematic substance use and mental health issues.
Children and Youth Services Review, 105, 104450.

[31] Hashemian, F., Farzian, M., \& Bakhshaei, M. H. (2019). Evaluation of prevalence, distribution and types of drug errors reported in Besat Medical Center of Hamadan during 2014-2015. Medical Science, 29(3).

[32] Hood, J. G. (2009). Service-learning in dental education: meeting needs and challenges. Journal of Dental Education, 73(4), 454-463.

[33] Ivins, N., \& Jones, N. (2020). Two-layer reduced compression system for lower limb wounds: a non-comparative evaluation. British Journal of Community Nursing, 25(Sup4), S10-S16.

[34] Jääskelä, P., Nykänen, S., \& Tynjälä, P. (2018). Models for the development of generic skills in Finnish higher education. Journal of Further and Higher Education, 42(1), 130-142.

[35] Jones, N. J., Ivins, N., Ebdon, V., Hagelstein, S., \& Harding, K. G. (2018). Neuromuscular electrostimulation on lower limb wounds. British Journal of Nursing, 27(20), S16-S21.

[36] Köksal, M. H. and Özgül, E. (2007). The relationship between marketing strategies and performance in economic crisis. Marketing Intelligence \& Planning, Vol. 25, No. 4, pp. 326-342.

[37] Kurtdede-Fidan, N., \& Aydogdu, B. (2018). Life Skills from the Perspectives of Classroom and Science Teachers. International Journal of Progressive Education, 14(1), 32-55.

[38] Lincoln, Y. G., \& Guba, E. (1985). E. 1985. Naturalistic Inquiry. London, Sage Publications. Contextualization: Evidence from Distributed Teams." Information Systems Research, 16(1), 9-27.

[39] Lumpkin, G T., and Dess, G. G. (1996). Clarifying the Entrepreneurial Orientation Construct and Linking it to Performance. Academy of Management Review, 21(1): 
135-172.

[40] Manogue, M., McLoughlin, J., Christersson, C., Delap, E., Lindh, C., Schoonheim-Klein, M., \& Plasschaert, A. (2011). Curriculum structure, content, learning and assessment in European undergraduate dental education-update 2010. European Journal of Dental Education, 15(3), 133-141.

[41] Martin, L. W., Sarosiek, B. M., Harrison, M. A., Hedrick, T., Isbell, J. M., Krupnick, A. S., Lau, C. L., Mehaffey, J. H., Thiele, R. H., \& Walters, D. M. (2018). Implementing a thoracic enhanced recovery program: lessons learned in the first year. The Annals of Thoracic Surgery, 105(6), 1597-1604.

[42] Nadeem, M. A., Qamar, M. A. J., Nazir, M. S., Ahmad, I., Timoshin, A., \& Shehzad, K. (2020). How Investors Attitudes Shape Stock Market Participation in the Presence of Financial Self-Efficacy. Frontiers in Psychology, 11(2286), 1-10. doi:10.3389/fpsyg.2020.553351

[43] Organization, W. H. (2001). The World Health Report 2001: Mental health: new understanding, new hope. World Health Organization.

[44] Pee, B., Woodman, T., Fry, H., \& Davenport, E. S. (2002). Appraising and assessing reflection in students' writing on a structured worksheet. Medical Education, 36(6), 575-585.

[45] Perry, B. C., Zhou, D., Wu, X., Yang, F.-C., Byers, M. A., Chu, T.-M. G., Hockema, J. J., Woods, E. J., \& Goebel, W. S. (2008). Collection, cryopreservation, and characterization of human dental pulpderived mesenchymal stem cells for banking and clinical use. Tissue Engineering Part C: Methods, 14(2), 149156.

[46] Peterson, Jennifer. (2019). The Role of Universities in Workforce Development, Gauisus, scholarship of teaching and learning (SoTL) publication Illinois State
University.

https://gauisus.weebly.com/petersonvolume7.html

[47] Price, J. B. (2019). Caries Detection with Dental Cone Beam Computed Tomography. In Detection and Assessment of Dental Caries (pp. 127-138). Springer.

[48] Rex, O. C. (2019). Poverty Elevation Amidst Poverty Alleviation Programmes In Nigeria. International Journal of Social Sciences and Economic Review, 1(2), 5460. https://doi.org/10.36923/ijsser.v1i2.38

[49] Ridner, S. H. (2004). Psychological distress: concept analysis. Journal of Advanced Nursing, 45(5), 536-545.

[50] Rose, O., Schaffert, C., Czarnecki, K., Mennemann, H. S., Waltering, I., Hamacher, S., Felsch, M., Herich, L., \& Köberlein, J. (2015). Effect evaluation of an interprofessional medication therapy management approach for multimorbid patients in primary care: a clusterrandomized controlled trial in community care (WestGem study protocol). BMC Family Practice, 16(1), 84.

[51] Sabalic, M., \& Schoener, J. D. (2017). Virtual reality-based technologies in dental medicine: knowledge, attitudes and practice among students and practitioners. Technology, Knowledge and Learning, 22(2), 199-207.

[52] Sampson, E. M., Udoh, V., Sampson, S. N. M., \& Abraham, C. (2019). Environmental And Socio-Economic Effects Of Timber Exploitation In Imo River Estuary, Eastern Obolo, Akwa Ibom State, Nigeria. International Journal of Social Sciences and Economic Review, 1(1), 22-28. https://doi.org/10.36923/ijsser.v1i1.29

[53] Schumpeter., J A (1939). Business Cycles A Theoretical, Historical and Statistical Analysis of the Capitalist Process. Harvad . II-Mcgraw Hill Book Company.

[54] Sopka, S., Biermann, H., Druener, S., Skorning, M., Knops, A., Fitzner, C., Rossaint, R., \& Beckers, S. (2012). 
Practical skills training influences knowledge and attitude of dental students towards emergency medical care. European Journal of Dental Education, 16(3), 179186.

[55] Tobins, A.J. (2005). Asking About Life. Thomson Brooks/Cole. Canada.

[56] Tucker, C. S. (2018). The Impact of Transfer Shock in a Dental Hygiene Program at a Four-Year Health-Sciences University.

[57] Wood, N. J., Jenkinson, H. F., Davis, S. A., Mann, S., O’Sullivan, D. J., \& Barbour, M. E. (2015). Chlorhexidine hexametaphosphate nanoparticles as a novel antimicrobial coating for dental implants. Journal of Materials Science: Materials in Medicine, 26(6), 201. 